\title{
Impact of Microclimate and Indoor Plants on Air Ion Concentration
}

\author{
Natalia Sinicina, Andris Skromulis, Andris Martinovs \\ Rezeknes Augstskola, Faculty of Engineering, Address: Atbrivosanas aleja 76, Rezekne, LV-4601,
} Latvia

\begin{abstract}
Saturation of air ions is essentially important for all living beings, especially for human health. Existing sanitary norms provide that concentration of small ions has to be in range of $400-50000$ ions $\mathrm{cm}^{-3}$ and unipolarity coefficient $0.4 \leq K \leq 1.0$. Many species of indoor plants emit organic volatile compounds and air ions, therefore they could be used for improving the quality of indoor air. The results show that ionization level of indoor air is significantly insufficient and selected species of indoor plants are not able to improve it. They serve rather as supplementary surfaces for ion absorption. Possible interaction between microclimate, ion concentration and indoor plants in different times of the day is analyzed.
\end{abstract}

\section{Keywords: air ions, indoor plants, microclimate.}

\section{INTRODUCTION}

Content of chemical substances or physical components are not the only factors characterizing quality of indoor air. Air is an environment where various types of physical fields concentrate and disperse. Many physical fields have an impact on the level of air ionization, giving energy necessary for air molecules to overcome the ionization barrier. Thus, the air becomes an environment that constantly contains certain amount of energy. In this case, it is necessary to talk about energetic saturation of air which inevitably affects living organisms. One of the most common descriptors of energetic saturation of the air is the level of air ionization, i.e. concentration of air ions in the air.

Atmospheric physics uses the term "air ions" to describe all airborne particles which have an electric charge and which assure electrical conductivity of air $[1,2]$. In a narrow sense, the term "air ions" means any airborne and charged particles whose size is from 0.36 to $79 \mathrm{~nm}$ and whose mobility is from 1.3 to 0.0042 $\mathrm{cm}^{2} \mathrm{~V}^{-1} \mathrm{~s}^{-1}$ (i.e., from unimolecular ion migrating in the air to aerosol particles whose upper size limit is not clearly defined). Usually, the upper limit of particles is considered to be $79 \mathrm{~nm}$ and mobility $0.00041 \mathrm{~cm}^{2} \mathrm{~V}^{-}$ ${ }^{1} \mathrm{~s}^{1}$. Charged particles within these limits are considered to be research objects of natural origin during air ion studies outdoors. To some extent, these limits are defined by sensitivity threshold of the air measuring device [3]. Nowadays, the most commonly used classification is based on physical structure of air ions [4]. Cluster ions contain only ionized and polarized gas molecules that form clusters, while the heaviest ions are aerosol ions which include not only ionized and polarized gas molecules but also atmospheric aerosol particles as ion condensation nuclei. Diameter of cluster ions is in range of 0.36 -
$1.6 \mathrm{~nm}$, and their mobility varies from 1.33 to 0.5 $\mathrm{cm}^{2} \mathrm{~V}^{-1} \mathrm{~s}^{-1}$.

Air ions affect a wide range of wildlife from microorganisms, animals, plants, human beings to ecosystems and even global climate. Many studies show and characterize the impact of air ions on human beings and all other living organisms [5]. Oxygen and other ionized molecules of air components have stronger effect on human organism. Air ions may be healing or may harmfully affect human health. This effect depends on ion concentration in the air and on proportions of positive and negative ions [6]. These proportions are characterized by unipolarity coefficient

$$
K=\frac{n^{+}}{n^{-}}
$$

where $\mathrm{n}^{+}$and $\mathrm{n}^{-}$mean concentration of positive and negative cluster ions.

The study carried out with primary school children in the U.S.A. shows that negative artificial air ionization in classrooms significantly increases physiological tolerance to stress factors thus reducing the impact of stress that manifests itself in nervous behavior of children, poor concentration skills and low educational attainments [7].

The content of positive and negative air ions in the air has a significant effect on physiological processes in human body, thus affecting the state of health, mental and physical performance, and well-being. In general, negative air ions have a positive impact on human health, whereas positive air ions are unfavourable [8].

In order to detect and evaluate the impact of air ions with various concentrations and different charge signs on human health, many experiments have been carried out on animals. For example, a therapy of negative air 
of animal bodies even in conditions of prolonged stress. This fact opens up opportunities to use the therapy of air ions for treatment of human neuroses [9]. The therapy of negative air ions has contributed to faster wound healing of laboratory rats and to improve their health [10]. The therapy of air ions can be used to improve human health and well-being, to treat burning wounds, injuries, and other diseases [11]. It is important to know that negative air ions have a disinfecting effect as well and that they prevent development of dangerous bacteria [12,13]. Information on air ion concentration necessary for optimal human operational capacities obtained during scientific studies $[14,15,16]$ are incorporated into national legislation of several countries. Studies on interaction between air ions and indoor air pollution with aerosols are described in numerous publications [17]. Air ionization technologies are widely used in purification of fine aerosols [18] and pathogenic bacteria [19] from indoor air.

On 16 June 2003, sanitary and epidemiological rules and regulations "Hygienic Requirements for the Air-Ion Level of Industrial and Public Facilities SanPin 2.2.4 1294-03" [35] (Санитарноэпидемиологические правила и нормативы "Гигиенические требования $к$ аэроионному составу воздуха производственных и общественных помещений СанПин 2.2.4 1294 03")" entered into force in the Russian Federation.

This regulatory document sets requirements for air ion contents in facilities where a variety of reasons may cause decreased or increased concentration of air ions inappropriate for human organism. The lowest concentration limit of air ions appropriate for human well-being is 400 ions $\mathrm{cm}-3$, while the highest appropriate ion concentration is $50000 \mathrm{~m}-3$. Unipolarity coefficient must be $0.4 \leq \mathrm{K} \leq 1.0$. In recent years, similar regulatory documents have been adopted in Ukraine and Belarus. However, neither the legislation of Latvia, nor regulatory documents of other EU's countries control the levels of air ion concentration in work or living facilities.

Air ions and plants influence each other. Artificially controlled environment of air ions in greenhouses is experimentally used to harvest more vegetables [13] because ionized air particles contribute to a faster exchange of substances in plants [24]. However, numerous cases show that air ions in combination with strong anthropogenic atmospheric pollution can also enhance negative effects on plants. Air ions of different classes, products of radon gas decay and charged aerosol particles which are spread in the atmosphere are considered to be factors causing damages of tree foliage and trunk [21].

Most plants emit different types of volatile organic compounds (Bio VOCs) and even micro-amount of Bio VOCs have a great impact on formation processes of cluster ions [22]. This effect is reinforced when volatile compounds are emitted from the plant in ionic form, e.g., Bio VOCs emitted from the needles of conifers are ionized because of charges accumulated in the sharp tips of the needles. Ions of volatile compounds are very good condensation nuclei in the atmosphere that contribute to further formation of mist and clouds. Thus, coniferous forests can affect even the global climate [23]. To a certain extent, most of the plants are air ion generators. Intensity of such generation depends on the daily intensity cycle of metabolic process in these plants [20].

Houseplants improve the quality of indoor air. Some plants effectively clean the air from organic contaminants [26], while other plants reduce the amount of microorganismes in the air because of phytoncide effect. Plants produce oxygen and absorb carbon dioxide [25,27]. Many plants intensely humidify the air of the room. As elements of phyto design, houseplants have a positive impact on the psycho-emotional state of the occupants. As a consequence of people staying indoors, the indoor air is saturated with anthropogenic organic, microbial and aerosol pollution to a greater extent than the natural air. The indoor air contains less small oxygen ions than the natural air [28].

Plants are the source of negatively charged ions. Light-absorbing pigments in photo-organisms capture photons of certain colors and reflect other colors. The energy of a photon through a long chain of molecules is transferred to the reaction center, which splits water to produce high-energy electrons for biochemical reactions. The process of photosynthesis (especially the light phase) is directly related to the change in the difference of potentials on the thylakoid membranes of chloroplasts [30,31].

Negative ions promote synthesis and maintenance of vitamins in human organism and stimulate physiological processes. Normally, the human organism requires daily 13 milliards of negatively charged ions. Central heating and cooling equipment reduce the amount of negative ions in the air. Besides, synthetic fibers and carpets containing positive charges can easily absorb the negative ions. They are also absorbed by steel armature and wooden chipboard [29].

Phytoncides ionize the oxygen in the air, thus increasing its biological activity. Phytoncides improve the efficiency and profitability of cell energy. Phytoncides promote settling of dust particles, reduce the electric index of air pollution and neutralize microorganisms in the air [32].

In 1994, a conference "With plants against smog" was held in Frankfurt-am-Main. Participants of this conference discussed the issue of environmental degradation in the indoor spaces. The conclusion reached by the participants of the conference is as follows: a significant improvement in the indoor air quality can be achieved using plants for greening [33]. Such indoor plants as geraniums and begonias reduce the concentration of microorganisms in the ambient air by $43 \%$, cyperus - by $59 \%$, Chrysanthemum parviflorum - by $66 \%$ [34]. Tradescantia effectively 
absorbs gas pollutants, intensively emits oxygen and phytoncides [28]. Studies conducted by NASA, the purpose of which was to find ways to purify the air in the space capsules, have found that some of indoor plants can clean the air of many pollutants, including formaldehyde. Such plants are Spathiphyllum Wallisii, Syngonium Podophyllum, Dwarf banana plants (Musa), Scindapsus or Epipremnum (Scindapsus Aureus). Plants of three different types were found to perform the same function, but they are not so effective indoors due to their long and sharp tips of leaves. Such plants are: Aglaonema, Chlorophytum (Chlorophytum Elatum), Sansiveria (Sanseveria Trifasciata Laurentii) [27].

It would be perspective to develop technology for artificial greening that would ensure air ion concentration and microclimate conditions indoors optimal for human organism. In order to develop such technology, it is necessary to find out changes in air ion concentration depending on indoor plants and microclimate.The aim of this research is to explore the impact of indoor plants and microclimate on air ion concentration in order to find opportunities to use plants for air quality improvement.

\section{Materials and methods}

In order to perform this study, several plants were selected which by their nature and taking into account the impact of external factors can affect the air ion concentration indoors. Therefore, plants with following characteristics were chosen: large area of leaves, leaves with a pointed tip and hair shaft; developed transpiration function (as a result of transpiration a lot of water is vaporized from plants), dust particle absorption, expressed phytoncide features.

A phyto-module was created (a complex of specially selected plants for environmental improvements) basing on the following plants: Chlorophytum - 2 pcs., Tradescantia - 2 pcs., Geranium (Pelargonium) - 2 pcs., Dracaena, Scindapsus Syngonium, Aglaonema, Spathiphyllum 2 pcs., Sansevieria, Echinocactus Grusonii -1 pc. For characteristics of these plants see Table 1 .

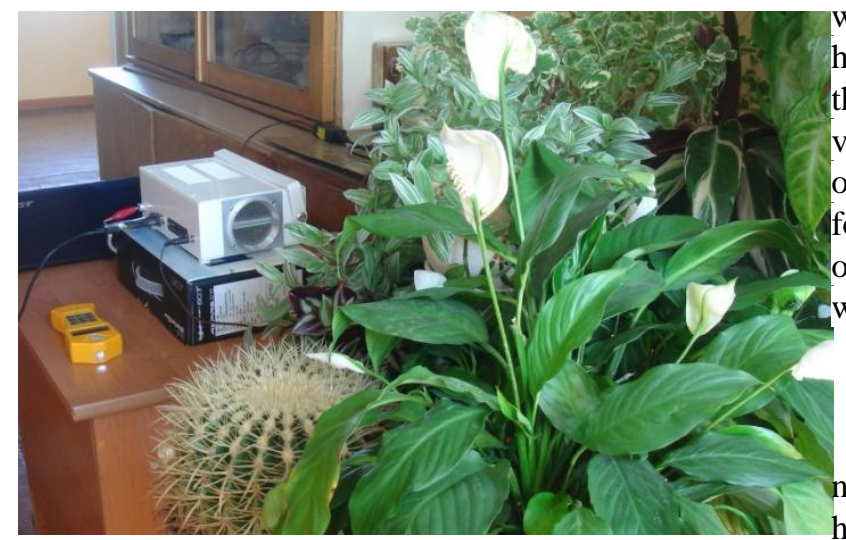

Fig. 1. Arrangement of measuring devices and plant group indoors
TABLE 1.

CHARACTERISTICS OF PLANTS [26]

\begin{tabular}{|c|c|c|c|c|c|}
\hline $\begin{array}{c}\text { Name / Number of } \\
\text { plants in } \\
\text { experiment } \\
\left(12 \mathrm{~m}^{2}, 36 \mathrm{~m}^{3}\right)\end{array}$ & $\begin{array}{l}\text { Lightening } \\
\text { requirements }\end{array}$ & $\begin{array}{c}\text { Phytoncide } \\
\text { features }\end{array}$ & $\begin{array}{c}\text { Intensity of } \\
\text { oxygen } \\
\text { generation }\end{array}$ & \begin{tabular}{|c|} 
Efficiency of \\
air purification \\
from gas \\
admixtures \\
(relative values) \\
$0-10$ \\
\end{tabular} & $\begin{array}{l}\text { Substances absorbed } \\
\text { efficiently }\end{array}$ \\
\hline Chlorophytum/2 & Indirect, bright & $*$ & *** & 7.8 & \begin{tabular}{c|}
$\begin{array}{c}\text { Formaldehyde, carbon } \\
\text { dioxide }\end{array}$ \\
\end{tabular} \\
\hline Tradescantia/2 & $\begin{array}{c}\text { From partial } \\
\text { shadow to sunny }\end{array}$ & ** & ** & 7.8 & \begin{tabular}{|c|}
$\begin{array}{c}\text { Formaldehyde, carbon } \\
\text { dioxide }\end{array}$ \\
\end{tabular} \\
\hline Geranium $/ 2$ & Indirect, bright & **** & $* * *$ & 6.9 & Formaldehyde, \\
\hline Dracaena/1 & $\begin{array}{c}\text { From partial } \\
\text { shadow to sunny }\end{array}$ & * & ** & 6 & Formaldehyde, acetone \\
\hline Scindapsus/1 & Indirect, bright & - & $*$ & 6 & 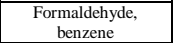 \\
\hline Syngonium/1 & \begin{tabular}{|l|} 
Indirect, dissipated \\
\end{tabular} & * & $* *$ & 7 & Formaldehyde, \\
\hline \begin{tabular}{|l|} 
Aglaonema/1 \\
\end{tabular} & Partial shadow & ** & $* * *$ & 6.8 & Benzene, toluene \\
\hline Spathiphyllum/2 & $\begin{array}{l}\text { Bright, in spring } \\
\text { dissipated }\end{array}$ & $*$ & ** & 7.5 & \begin{tabular}{c|} 
Formaldehyde, \\
acetone, chloroethene, \\
benzene
\end{tabular} \\
\hline Sansevieria/1 & Bright & * & * & 6.8 & \begin{tabular}{|c|} 
Formaldehyde, \\
acetone, chloroethene, \\
benzene
\end{tabular} \\
\hline
\end{tabular}

Air ion concentration was determined with a portable bipolar air ion counter "Sapfir-3м" (see Fig.1). It provides simultaneous measuring of positive and negative air ions with minimum resolution of 10 ions per $1 \mathrm{~cm}^{3}$. The device measures air ion concentration in the air (mobility $\mathrm{k} \geq 0.4 \mathrm{~cm}^{2} \mathrm{~V}^{-1} \mathrm{~s}^{-1}$ ) in the air. This mobility interval nearly corresponds to the class of cluster ions [4]. During the measurements, air ions, according to their polarities, are channelized to positive or negative aspiration collector in aspiration chamber and after coming into contact with this collector the ions are discharged. Afterwards, the charge is sent to amplifiers from which impulses are counted and displayed on the display. The charges of air ions are counted in the device, therefore if the ion has more than one charge, it is counted as several ions.

Indoor climate parameters were determined with a multimeter "Easy Sense Q". The systematic measurement error of this device for temperature is \pm $0.3^{\circ} \mathrm{C}$, whereas the error for relative humidity is \pm $5 \%$. The error for lighting is not specified, but its maximum measurable value is $1000 \mathrm{Lx}$. The total amount of radioactive $\alpha, \beta$ and $\gamma$ radiation was measured in $\mu \mathrm{Sv} \cdot \mathrm{h}^{-1}$ with a portable device "GammaScout" with systematic measurement error less then $5 \%$. For all devices each measurement point is defined as the average value of 10 minutes.

The measurements were carried out in automatic mode: $24 \mathrm{~h}$ without plants and $24 \mathrm{~h}$ with plants that were placed in a room of $12 \mathrm{~m} 2$ and $36 \mathrm{~m} 3$. The room has one window towards SW. The room is located on the first floor, it is closed and without forced ventilation. During the measurements, the heating was on. People were present in the room only 1 time a day for $30 \mathrm{~min}$. to switch on the devices and to at just online mode for measuring. All daily measurements were repeated two times.

\section{RESULTS AND DISCUSSION}

The experimental data (see Fig.2) show that the number of positive air ions in the given rooms is higher than the number of negative air ions: $15-25 \%$ (without houseplants) and 100-150\% (with houseplants). Maximum / minimum concentration of 
positive air ions: $320 \mathrm{~cm}-3 / 60 \quad \mathrm{~cm}-3$ (without houseplants) and $345 \mathrm{~cm}-3 / 60 \mathrm{~cm}-3$ (with houseplants). Maximum/minimum concentration of negative air ions: $260 \mathrm{~cm}-3 / 40 \mathrm{~cm}-3$ (without houseplants) and 220 $\mathrm{cm}-3 / 40 \mathrm{~cm}-3$ (with houseplants). If there are no plants in the room, the concentration of positive and negative air ions is approximately two times higher in the night than during the day. If there are plants, the concentration of positive and negative ions is approximately two times lower in the night than during the day. These data suggest that, basing on the air ion concentration and unipolarity coefficient, the room used for the experiments is not recommended for human health (if not ventilated). The room has very low concentration of positive and negative air ions and inadequate unipolarity coefficient, because basing on the SanPin 2.2.4 1294-03 minimal admissible concentration of positive air ions is $400 \mathrm{~cm}-3$, negative air ions $600 \mathrm{~cm}-3$, admissible values of unipolarity coefficient $\leq 0.4 \mathrm{~K}<1.0$.

During the day, the room temperature is increased and relative humidity is decreased because of the sunlight. The measured average ambient temperature in the room with plants is about $10 \mathrm{C}$ higher than in the room without plants. The average humidity is about $1 \%$ higher in the room with plants than in the room without plants (first measurement series) or the same as in the room without plants (second measurement series) (See Fig.2). It means that plants increase the air humidity (the water is evaporated through leaf pores).

Basing on the literature analysis and experimental research, the following factors influencing air ion concentration may be defined:

1) natural radiation splits neutral air molecules thus creating positive ions and electrons, therefore the number of positive and negative ions in the air is increased;

2) photo-ionization: as a result of lighting or other electromagnetic radiation, electrons are detached from neutral air molecules thus increasing the number of positive ions in the air; the higher the frequency of electromagnetic radiation (higher photon energy) and lower ionization energy of air molecules, the more free electrons and positive ions occur;

3) photo-effect: as a result of lighting or other electromagnetic radiation, free electrons are detached from surfaces, dust and aerosol particles; the higher the frequency of electromagnetic radiation, larger the surface area, more dust / aerosol particles and smaller electron's exit work for the surface material, the more free electrons are sent into the air; it increases the number of negative air ions; as a result of photo-effect the adsorbent surface (walls, furniture, curtains, plant leaves, human body, clothing, dust / aerosol particles, etc) is charged positively; it promotes the absorption of negative air ions but reduces the absorption of positive air ions (are repulsed away from the surface); the stronger is positive charge of the surface, the harder it is to knock out electrons from it;
4) organic compounds (phytoncides) emitted by plants into the air; a part of these compounds may have already been ionized during the process of emission from the plants; other compounds may be ionized as a result of natural radiation or light; this factor increases the concentration of positive and negative air ions; the speed of phytoncide emission depends on the process of metabolism in the plants which is largely determined by plant species, lighting and, possibly, by plant watering regime;

5) surface adsorption properties: the stronger is surface absorption of air ions, the lower is ion concentration in the air; it is possible that surface adsorption properties may be changed because of lightening (internal photo-effect activate surface of ion absorption: separate positively and negatively charged microscopic areas are created which promote air ion adsorption); absorption properties of different plant species are different;

6) surface area of ion adsorption: the larger surface area, the more ions are adsorbed; it decreases the amount of positive and negative ions in the air (if the photo-effect is not taken into account); if the photoeffect is taken into account, the enlargement of surface area increases the number of negative ions and free ions created by photo-effect; during the night (no photo effect) air ion absorption prevails, while during the day both photo-effect and air ion adsorption may prevail;

7) dustiness: the more dust particles in the air, the greater possibility for positive and negative ions to adsorb on the surfaces of these particles; the increase of concentration of dust particles decreases the amount of positive and negative air ions (ignoring the photo-effect); if the photo-effect is taken into account, the increase of dust particles increases the number of negative ions and free ions created by photo-effect; during the night (no photo effect) air ion absorption prevails, while during the day both photo-effect and air ion adsorption may prevail;

8) air humidity: the higher the humidity, the more aerosol particles in the air and greater possibility for positive and negative ions to adsorb on the surfaces of these particles; it decreases the amount of positive and negative ions (ignoring the photo-effect); if the photoeffect is taken into account, the increase of aerosol particles increases the number of negative ions and free ions created by photo-effect; during the night (no photo effect) air ion absorption prevails, while during the day both photo-effect and air ion adsorption may prevail; the presence of plants in the room increases the level of air humidity; air humidity might be influenced by plant watering regime;

9) temperature: the higher is the temperature, the easier it is to ionize neutral air molecules; it increases the number of positive and negative air ions; the rise of temperature reduces humidity; its impact on the amount of air ions may be seen in the description of factor No.8; 
10)recombination of positive and negative air ions; the higher concentration and mobility of positive and negative air ions, the greater chance for ions to disappear by reciprocal recombination;

11)the Earth's electrical field and the convection air flow in the room promotes movement of air ions and their disappearance after contact with surfaces;

12)characteristics of surface absorbing the ions (e.g., the surface is smooth, rough, sharp), its shape and position (horizontal, vertical).

Air ion concentration is affected by all the above mentioned factors. In each specific case the impact of each factor on air ion formation process is different.
Unfortunately, it is not possible to give an unambiguous explanation of experimental results of the studies on factors influencing air ion concentration. For a complete understanding of the process, it is necessary to carry out experiments which explore the specific impact of each separate factor on the amount of air ions (studies of air ion concentration changes depending on one factor, excluding, as far as possible, all other factors). In order to predict air ion concentration changes over time, it is necessary to create a mathematical model that includes all the studied factors and their characteristics and where constants characterizing each factor are experimentally determined.
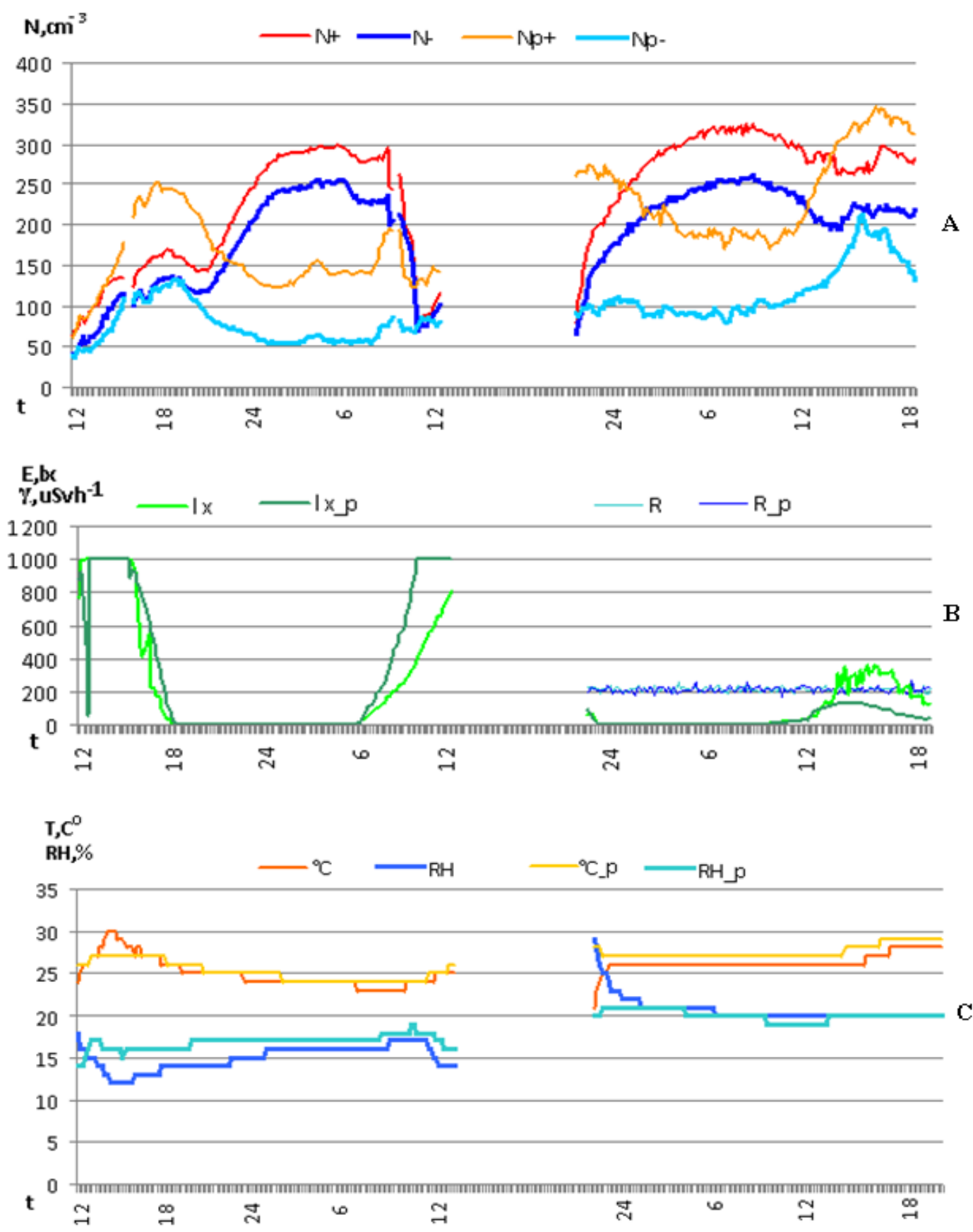

Fig. 2. Experimental results

A. Concentration of positive and negative air ions indoors; B. Measurements of lightening and radiation background indoors;

C. Measurements of temperature and relative humidity indoors 


\section{Sinicina N., Skromulis A., Martinovs A. IMPACT OF MICROCLIMATE AND INDOOR PLANTS ON AIR ION CONCENTRATION}

In order to explain the experimental results to a first approximation (see Fig.2), the following simplifications are made:

1) as the natural radiation level (factor 1) fluctuates chaotically around the average value $215 \mu \mathrm{Sv} \bullet \mathrm{h}-1$ and the amplitude of these fluctuations is less than $10 \%$, the level of radiation can be considered as constant; fluctuations of radioactive background do not affect daily changes of air ion concentration;

2) since the room is small and closed, the air convection flow is insignificant and dustiness (factor 7) is not changed;

3 ) temperature (factor 9), air humidity (factor 8), the Earth's electric field (factor 11) are approximately constant;

4) as the concentration of positive and negative air ions is low (maximum concentration of positive ions $345 \mathrm{~cm}-1$, negative ions $260 \mathrm{~cm}-1)$, the recombination effect (factor 10) is insignificant;

5) the concentration of air ions is not significantly affected by characteristics of adsorptive surface or its shape and location (factor 12).

Thus, the experiments show that the established air ion concentration changes in this case are primarily affected by factors $2,3,4,5$ and 6 . These factors are related to the changes of lighting, surface area, type (room with plants or room without plants) and absorbent characteristics.

It is necessary to explain the Fig. 2 showing daily process of concentration changes of positive and negative air ions in room with plants and in room without plants.

Plants used in the experiments are producers and absorbers of positive and negative air ions. During the night, the process of plant's metabolism and ion emission into the air slows down; during the night, the plants mainly adsorb air ions. Therefore, during the night a significant decrease in air ion concentration can be observed in the room with plants. During the day metabolic processes in plants are activated; plants emit positive and negative ions into the air and simultaneously adsorb these ions. During the day, electrons are knocked out from plant surfaces as a result of photo-effect. These electrons increase the amount of negative air ions. At the same time the plant surfaces are charged positively; it increases the adsorption of negative air ions and decreases the absorption of positive ones. As a result, during the day the room with plants has increased concentration of air ions (especially positive ones).

It is experimentally established that during the day the concentration of positive and negative air ions in the room with plants decreases (in comparison with night). It can be explained as follows: as a result of the lighting the surfaces absorbing air ions are activated; photons do not knock the electrons out of the surface but only disconnect them from the surface atoms creating free electrons (internal photo-effect); as in most cases the adsorbent surfaces are dielectrics, the free electrons resulting from such internal photo-effect do not flow away but create negatively charged and microscopic areas on these surfaces; the place from which the electron has been separated is positively charged; such positively and negatively charged microscopic areas on surfaces promote air ion adsorption; it also reduces air ion concentration during the day. During the night, the process of internal photo-effect is interrupted, therefore the charged surface areas gradually disappear and the adsorption process is decreased, while air ion concentration is increased (air ions are produced by natural radiation).

\section{CONCLUSION}

1. The authors of this research carried out experimental studies on total concentration changes of positive and negative air ions in a closed room $\left(12 \mathrm{~m}^{2}\right.$, $36 \mathrm{~m}^{3}$ ). Level of natural radiation, light, temperature and relative air humidity in room with and without plants were measured as well. It was found that during the day air ion concentration is approximately two times increased if compared to the night (if there are plants in the room) (see Table 1). If micro-climatic conditions are almost the same in a room without plants, the changes in air ion concentration are opposite: during the day, air ion concentration is decreased, while during the night it is increased (by $20-100 \%$ ).

2. Basing on the used information sources and experimental studies, 12 factors influencing air ion concentration were selected. In each specific case the role of each factor in the air ion formation process is different. For complete understanding of the process, it is necessary to carry out experiments to establish the role of each factor on the amount of air ions separately and to create a mathematical model including all selected factors. Such model would enable development of a methodology for anticipation of air ion concentrations and for optimization of indoor air quality with the help of houseplants.

3. Further experiments could be related to changes in air ion concentration depending on plant species, number, leaf shape, area and roughness, plant watering regime, lighting, temperature, air humidity, characteristics of surfaces located in the room. The aim of such studies would be to find the plants, their life conditions and to find the surface coatings in order to provide air ion concentration that would be optimal for human health indoors.

\section{ACKNOWLEDGMENTS}

This study was supported by the research project of the Latvian Council of Science „Development of technology for the creation of multicomponent nanostructured protective coatings for industrial products" No. 10.0009, subproject No.3 "Modeling and assessment of ecological safety during technological processes of sputtering of coating". 


\section{Sinicina N., Skromulis A., Martinovs A. IMPACT OF MICROCLIMATE AND INDOOR PLANTS ON AIR ION CONCENTRATION}

\section{REFERENCES}

[1] Dolezalek H., Reiter R., Kröling P. (1985) Basic comments on the physics, occurrence in the atmosphere, and possible biological effects of air ions. Int. J. Biometeorol., No. 29, pp. 207-242

[2] Tammet H. (1998) Air ions. In: CRC Handbook of Chemistry and Physics, 79th edition, No. 14, Boca Raton, Ann Arbor, London, Tokyo: CRC Press, 1998, pp. 32-34.

[3] Tammet H. (2011) Symmetric Inclined Grid Mobility Analyzer for the Measurement of Charged Clusters and Fine Nanoparticles in Atmospheric Air. Aerosol Science and Technology, No. 45, pp. 468-479.

[4] Hõrak U., Salm J., Tammet H. (2000) Statistica characterization of air ion mobility spectra at Tahkuse Observatory: classification of air ions. J. Geophys. Res. Atmos., No. 105, pp. 9291-9302.

[5] Rim Y. (1977) Psychological Test Performance of Different Personality Types on Sharav Days in Artifical air Ionisation. Int. J. Biometeor., Vol. 21, number 4, pp 337 - 340

[6] Charry J. M. (1984) Biological effects of small air ions: A review of findings and methods. Environmental Research, Vol. 34, Issue 2, pp. 351-389.

[7] Fornof K.T., Gilbert G.O. (1988) Stress and physiological, behavioral and performance patterns of children under varied air ion levels, Int J. Biometeorol, No. 32, pp. 260-270.

[8] Danze, J.M. L'ionisation de l'oxygene. [Elektronic resource]/ (16.08.2007.) http://www.delvaux-danze.be/ioniation.htm

[9] Livanova L. M., Levshina I. P., Nozdracheva L. V., Elbakidze M. G., Airapetyants M. G. (1999) The Protective Effects of Negative Air Ions in Acute Stress in Rats with Different Typological Behavioral Characteristics, Neuroscience and Behavioral Physiology, Vol. 29, No. 4, pp. 393-395.

[10] Jaskowski J., Mysliwski A. (1986) Effect of air ions on healing of wounds of rat skin. Experimental Pathology, Vol. 29, Issue 2, pp. 113-117.

[11] Герасимова Л. И., Данилов Ю. А., Евстигнеев А. Р., Мачабели М., С., Тихонов В. П. (1996) Аэроионотерапия. Калуга: Лазерная Академия Наук Российской Федерации, 1996 , c. 5-13.

[12] Krueger A. P., Smith R. F., Go I. G. (1957) The Action of Air Ions on Bacteria: Protective and Lethal Effects on Suspensions of Staphylococci in Droplets. JGP, Vol. 41, No. 2, pp. 359-381.

[13] Kellogg E. W. (1984) Air Ions: their Possible Biological Significance and Effects. Electromagnetic Biology and Medicine, Vol. 3, No.1-2, pp. 119-136.

[14] Рейнет Я. Ю. (1983) О Нормах аэроионов в помещениях. Ученые записи Тартуского Государственного Университета, No. 648, с. 46-51.

[15] Hawkins L. H., Barker T. (1978) Air Ions on Human Performance. Ergonomics, Volume 21, Issue 4, pp. 273-278.

[16] Hawkins L. H. (1981) The influence of air ions, temperature and humidity on subjective wellbeing and comfort. Journal of Environmental Psychology, Vol. 1, Issue 4, pp. 279-292.

[17] Прийман Р. Э. (1984) О понятии "Свежесть воздуха". Ученые записи Тартуского Государственного Университета, No. 669, с. 115-121.

[18] Shiue A., Hu S. C. (2011) Contaminant particles removal by negative air ionic cleaner in industrial minienvironment for IC manufacturing processes. Building and Environment, Vol. 46, Issue 8, pp. 1537-1544.

[19] Kim Y. S., Yoon K. Y., Park J. H., Hwang J. (2011) Application of air ions for bacterial de-colonization in air filters contaminated by aerosolized bacteria. Science of the Total Environment, Vol. 409, Issue 4, pp. 748-755.

[20] Wang J., Li S. H. (2009) Changes in negative air ions concentration under different light intensities and development of a model to relate light intensity to directional change. Journal of Environmental Management, Vol. 90, Issue 8, pp. 2746-2754.

[21] Tammet H. and Kimmel V. (1998) Electrostatic deposition of radon daughter clusters on the trees. J. Aerosol Sci. 29, pp. 473-S474

[22] Hoffmann T., Bandur R., Marggraf U., Linscheid M. (1998) Molecular composition of organic aerosols formed in the $\alpha$ pinene/O3 reaction: Implications for new particle formation processes. Journal of Geophysical Research: Atmospheres (1984-2012) Vol. 103, Issue D19, pp. 25569-25578.

[23] Kulmala M., Hämeri K., Aalto P.P., Mäkelä J. M., Pirjola L., Douglas Nilsson E., Buzorius G., Rannik Ü., Dal Maso M., Seidl W., Hoffman T., Janson R., Hannson H.-C., Viisanen Y., Laaksonen A., O'Dowd C. D. (2000) Overview of the international project on biogenic aerosol formation in the boreal forest (BIOFOR). Tellus B, Vol. 53, Issue 4, pp 324343.

[24] Скипетров В. П., Еникеев О. Л., Зорькина А. В., Иничина В. И., Мартынова В. В. (1995) Аэроионы и жизнь. Саранск: Изд-во Мордов. университета, 1995, 96 с.

[25] Г.Л.Спичкин, К.В.Воробьев, М.П.ФеО.В. Войцеховскаядоров, О.Ю.Кудрявцев. Влияние антропогенных аэроионных воздействий на фотосинтез Tradescantia fluminensis Vell. Санкт-Петербургский государственный политехнический Университет Ботанический Институт им. В. Л. Комарова РАН [Elektronic resource]/OOО «НПО «Фитотехнология» http://phyteco.ru/o_nas/publikatsii (01.03.2013)

[26] М.П. Федоров, Г.Л. Спичкин, К.В.Воробьев, О.Ю.Кудрявцев. «Комнатные растения против органических загрязнителей». Экология и жизнь, № 11(84), 2008, 80. - 85. lpp [Elektronic resource]/http://www.ecolife.ru/arhiv/flash/84\%28112008\%29.html (15.03.2013)

[27] Цыбуля Н.В., Фершалова Т.Д. Фитонцидные растения в интерьере (оздоровление воздушной среды с помощью растений). - Новосибирск: Новосибирское книжное издво, $2000-112$. 1pp.

[28] Федоров М.П., Воробьев К.В., Замараева В.С., Спичкин Г.Л. «Аэроионы для здоровья». Экология и жизнь, № 8(81), 2008, 78. - 82. 1pp.[ Elektronic resource]/http://www.ecolife.ru/arhiv/flash/81\%2882008\%29.html- (15.03.2013)

[29] Воздушные «витамины»- отрицательно заряженные ионы [Elektronic http://www.lucklife.net/view_lucklife/378.htm-_ Resurss apskatīts (27.03.2013)

[30] Duddington C.L. Evolution in plant design. London. 1969. $304 . \quad 1 p p$.[Elektronic resource]/ http://catalogue.nla.gov.au/Record/1852814.pdf (10.03.2013)

[31] Николас Д. Биоэнергетика. Введение в хемиосмотическую теорию. М., Мир, 1985.g. 146.lpp. [Elektronic

resource]/http://cyberpirate.me/bittorrent/viewtopic.php?t=37 70865 (10.03.2013)

[32] Сорокина А. «Кладовая здоровья на грядке и в лесу» [Elektronic resource] http://maga3in.ru/Library.asp?DocId=113\&SecId=6\&ord=5 (15.03.2013)

[33] Фитостена: как создать тропический сад у себя дома -[ Elektronic resource] http://www.moydesign.ru/book/export/html/1190 (15.03.2013)

[34] Ю. Синадский «Целительные силы природы» -[ Elektronic resource] http://www.florets.ru/tainy-rastenii/tselebnyivozduh.html (15.03.2013)

[35] Санитарно-эпидемиологические правила и нормативы "Гигиенические требования к аэроионному составу воздуха производственных и общественных помещений СанПин 2.2.4 1294-03") 